\title{
Limited Stage Lung Small Cell Carcinoma
}

National Cancer Institute

\section{Source}

National Cancer Institute. Limited Stage Lung Small Cell Carcinoma. NCI Thesaurus. Code C7853.

Small cell lung carcinoma which is confined to one hemi-thorax and the regional lymph nodes. 